\title{
Hamel cerebro-palato-cardiac syndrome
}

INSERM

\section{Source}

INSERM. (1999). Orphanet: an online rare disease and orphan drug data base. Hamel cerebro-palato-cardiac syndrome. ORPHA:93946

Hamel cerebro-palato-cardiac syndrome is an X-linked intellectual disability syndrome (XLMR; see this term) characterized by intellectual deficiency, microcephaly and short stature. It belongs to the group of disorders collectively referred to as Renpenning syndrome (see this term). 